\title{
Ningbo International Trade and Its Influence on Economic Growth
}

\author{
Zhixiong Gao, Jing Peng and Shanbo Ma
}

School of Economic and Management, Ningbo University of Technology, Ningbo, P.R.China, 315211

\author{
gzxuibe@126.com, nbcpengj@sohu.com,787355582@qq.com
}

\begin{abstract}
Keywords: Ningbo international trade; Economic growth; Trade competitiveness index; Trade structure
\end{abstract}

\begin{abstract}
As a coastal city, Ningbo is the main force to participate in the one belt and one road initiative. This paper analyzes the current situation of Ningbo international trade in aspect of composition of trade commodity, geographical distribution, the competitiveness of electromechanical and high-tech products. Based on 6 county-level cities panel data during 2005 to 2014, this paper also empirically studies the impact of trade on economic growth. The results demonstrate that Ningbo international trade has increased rapidly since 1985, its export or import market mainly concentrate in developed regions or close to Ningbo city, Ningbo exports labor intensive products and imports technology intensive ones, electromechanical products have stronger competitiveness. The empirical results prove a positive and significant impact of trade on economic growth.
\end{abstract}

\section{Introduction}

As a historical coastal city for international trade, located in eastern Zhejiang province, China, Ningbo became one of three biggest ports for foreign trade in Tang Dynasty together with Yangzhou and Guangzhou, and with Guangzhou and Quanzhou in Song Dynasty. It is the birthplace of the "Neolithic Hemudu Culture" dating back more than 7,000 years. Partly owing to the advantaged conditions, the economy of Ningbo has been developed rapidly since opening up to the world in 1978. It was in 1982 that Ningbo port began to import and export commodity, 3 years later, Ningbo got direct import and export rights. Ningbo import and export has developed rapidly at compound average growth rate of $35.8 \%$, more than its gross domestic product average growth rate $(17 \%)$ since 1985. Nowadays, Ningbo has become an important industrial city and an international trade port in East China, a key vice provincial city and chemical industrial base in Yangtze River Delta and an economic center of Zhejiang Province.

In September and October 2013, Chinese President Xi Jinping raised "One Belt, One Road" vision during visiting to Kazakhstan and Indonesia respectively. "One Belt and One Road", the strategic conception of building the "New Silk Road Economic Belt" and "21st Century Marine silk road in the 21st century", is a Chinese framework for organizing multinational economic development primarily in Eurasia through two main components. As a coastal city, Ningbo is positioned as the main force in participating in one belt and one road initiative according to Vision and Actions on Jointly Building Silk Road Economic and 21st-Century Maritime Silk Road Issued by the National Development and Reform Commission, Ministry of Foreign Affairs, and Ministry of Commerce of the People's Republic of China, with State Council Authorization. In the future, Ningbo will make great efforts to become the three first choice city between the cooperation of China with central and eastern Europe countries, i.e. two-way investment cooperation, central and eastern Europe to enter the Chinese market, cultural exchanges between China and the central and eastern Europe countries.

Therefore, it is important to study Ningbo international trade and empirically test its impact on economic growth. Most of the papers analyzed qualitatively or quantitatively Ningbo international trade and its influence[8], and few of them did the studies using econometric model. The contribution of this paper lies in the empirical studies of trade impact on the economy by 6 county-level cities panel data during 2005 to 2014. 
This paper is structured as follows: Section 2 describes the development and characteristics of Ningbo international trade. Section 3 empirically test the influence on Economic growth. Section 4 is the conclusions.

\section{Current Status of Ningbo Import and Export}

Overview of Ningbo International Trade. It was on February 14, 1985 that Ningbo textile import \& export company was founded, which is the first import \& export company integrating industry enjoying the right of import and export in Ningbo city. After that time, Ningbo started to import and export merchandise directly and its trade volume in goods increased in decades. The value of import and export was only $\$ 10.3$ million in 1985 , In 1993 , the total value was over 1 billion US dollars first time, reached $\$ 1.7$ billion, 165 times as much as that in 1985 , export value reached $\$ 1.1$ billion, import value was $\$ 586$ million. In 2013 , the international trade volume of Ningbo exceeded $\$ 100$ billion, reached $\$ 100.3$ billion, and rose to $\$ 100.5$ billion in 2015 , averaging an annual growth of 35.8 percent, the import value was $\$ 29.0$ billion, showing 32.4 percent annual growth on average, and the total value of its export expanded to $\$ 71.4$ billion, showing 38.7 percent annual growth on average( Figure 1). In 2015, the total volumes of Ningbo's export and import accounted for 28.9 percent of Zhejiang Province's total.

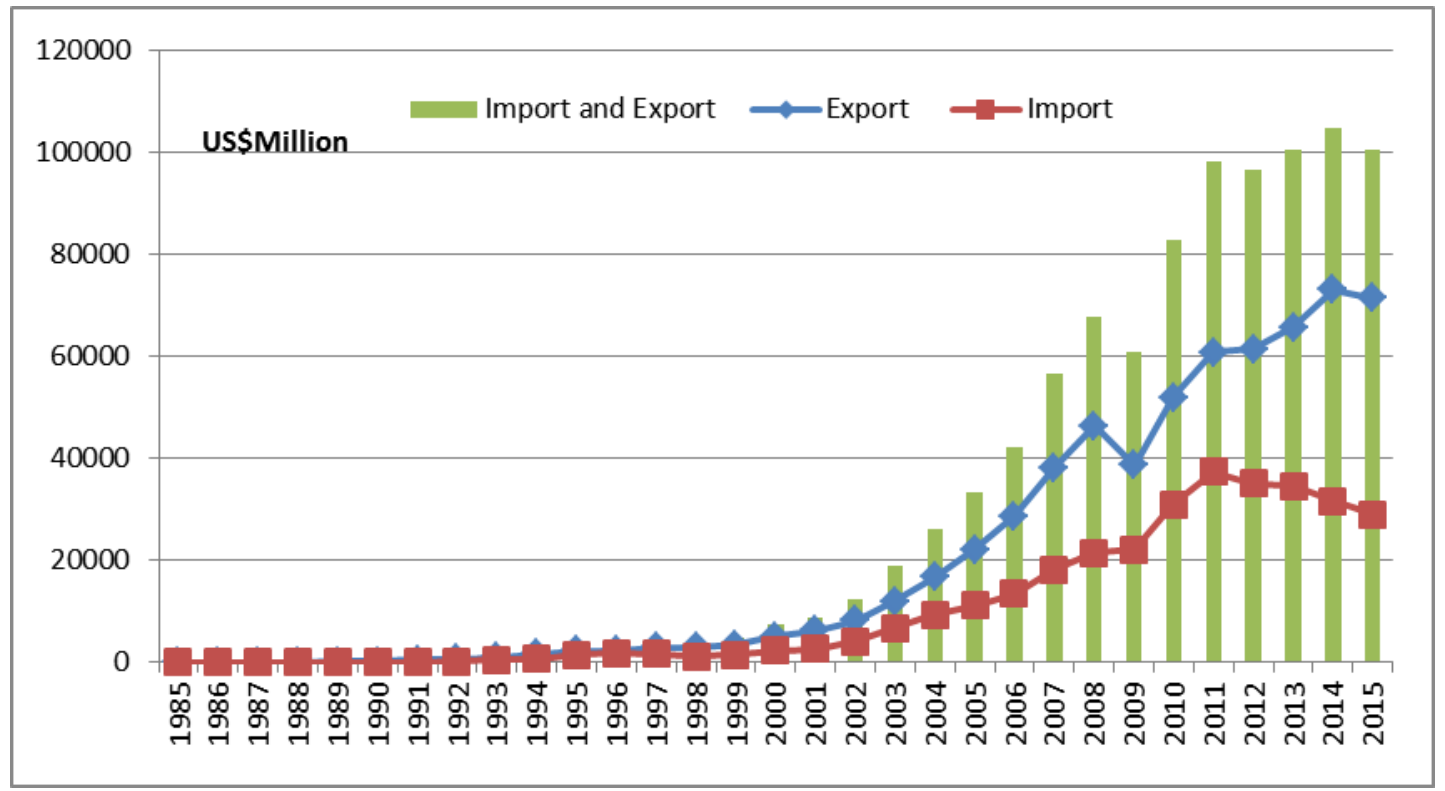

Figure 1. Ningbo direct import and export goods, 1985-2015

Source: Ningbo Statistical Yearbook 2015, http://www.nbstats.gov.cn/tjnj/2004njbg.htm.

Composition of Trade Commodity. About $60 \%$ import commodity summarize 3 kinds of merchandise in Ningbo, namely, raw material or resource material, high-tech electronics products and chemical materials. During 2005-2015, the major imported products listed as table 1 (selected from top 20 imported products each year ):

Among the imported products, technology intensive products, such as electromechanical products and high-tech products took up $44.8 \%$ in 2005 , decreasing to $30.1 \%$ in 2015 . As can be seen from table 2 , the share of electromechanical products in total import volume was reducing from 2005 to 2015, the share of high-tech products in total import volume rose and fell from 2005 to 2011 , trending to drop. 
Table 1 Ningbo's import commodity structure 2005-2015[\%]

\begin{tabular}{|c|c|c|c|c|c|c|c|c|c|c|c|}
\hline & 2005 & 2006 & 2007 & 2008 & 2009 & 2010 & 2011 & 2012 & 2013 & 2014 & 2015 \\
\hline Styrene & 3.86 & 3.66 & 4.25 & 3.58 & 3.27 & 2.57 & 1.50 & 2.04 & 3.57 & 2.71 & 3.21 \\
\hline Rolled Steel & 9.13 & 3.55 & 2.96 & 3.12 & 2.77 & 1.96 & 1.96 & 1.47 & 0.95 & 1.10 & 0.96 \\
\hline $\begin{array}{l}\text { Nickel not } \\
\text { Forged }\end{array}$ & 1.31 & 1.94 & 2.43 & & & 4.06 & 3.45 & 3.20 & 1.23 & & \\
\hline $\begin{array}{l}\text { Ethylene } \\
\text { Glycol }\end{array}$ & 1.85 & 1.70 & 1.41 & 1.32 & 0.92 & 1.27 & 1.51 & 1.46 & 1.54 & 1.41 & 0.96 \\
\hline Paper Pulp & 1.61 & 2.08 & 2.19 & 2.56 & 2.59 & 2.08 & 1.72 & 1.59 & 1.64 & 1.97 & 2.30 \\
\hline $\begin{array}{l}\text { Integrated } \\
\text { Circuits }\end{array}$ & 3.91 & 3.71 & 3.78 & 2.99 & 2.24 & 1.97 & 1.57 & 1.96 & 2.28 & 3.30 & 3.64 \\
\hline Iron Ore & 2.62 & 2.42 & 3.24 & 6.64 & 8.38 & 8.29 & 9.96 & 9.41 & 11.20 & 9.80 & 7.11 \\
\hline $\begin{array}{l}\text { Plastic in } \\
\text { Primary Form }\end{array}$ & 10.29 & 10.63 & 8.99 & 8.42 & 14.02 & 10.23 & 9.36 & 10.93 & 11.14 & 12.23 & 13.33 \\
\hline $\begin{array}{l}\text { Terephthalic } \\
\text { Acid }\end{array}$ & 2.77 & 2.48 & 2.07 & 1.14 & 1.01 & 1.25 & 1.43 & 1.18 & & & \\
\hline $\begin{array}{l}\text { Waste } \\
\text { Plastics }\end{array}$ & & 1.64 & 2.19 & 1.92 & 1.85 & 1.85 & 1.92 & 1.91 & 1.88 & 1.57 & 1.27 \\
\hline LCD panel & & & 4.46 & 12.07 & 8.81 & 8.55 & 6.62 & 7.59 & 5.72 & 5.64 & 4.08 \\
\hline $\begin{array}{l}\text { Not the } \\
\text { Forging of } \\
\text { Copper And } \\
\text { Copper } \\
\end{array}$ & & 1.29 & 2.51 & 1.99 & 4.56 & 5.84 & 4.73 & 3.20 & 2.16 & 3.16 & 2.09 \\
\hline Xylene & & & & 4.74 & 4.51 & 2.71 & 5.94 & 6.18 & 6.04 & 6.76 & 6.72 \\
\hline Cereal & & & & 2.43 & 2.03 & 1.90 & 1.78 & 1.89 & 0.93 & & \\
\hline Coal & & & & 0.00 & 0.75 & 0.70 & 1.47 & 1.39 & 1.61 & 1.60 & 1.28 \\
\hline $\begin{array}{l}\text { Textile Yarn, } \\
\text { Fabrics and } \\
\text { Related } \\
\text { Products } \\
\end{array}$ & & & & 1.20 & 1.19 & 1.04 & 1.04 & 1.61 & 1.79 & 1.91 & 2.32 \\
\hline $\begin{array}{l}\text { Non-Foam } \\
\text { Plastic Plate } \\
\text { Film Foil }\end{array}$ & & & & 0.85 & 1.03 & 1.05 & 1.09 & 1.17 & 1.11 & 1.20 & 1.01 \\
\hline Scrap Metal & & & & 7.39 & 6.83 & 10.39 & 11.14 & 11.52 & 10.61 & 8.63 & 7.50 \\
\hline
\end{tabular}

Source: Original data collected from Ningbo Municipal Commission of Commerce, authors calculated.

Table 2 The share of high-tech products and electromechanical products in Ningbo, 2005-2015[\%]

\begin{tabular}{|l|c|c|c|c|c|c|c|c|c|c|c|}
\hline & 2005 & 2006 & 2007 & 2008 & 2009 & 2010 & 2011 & 2012 & 2013 & 2014 & 2015 \\
\hline $\begin{array}{l}\text { Electromec } \\
\text { hanical } \\
\text { Products }\end{array}$ & 27.27 & 24.87 & 26.26 & 28.50 & 22.62 & 21.00 & 18.03 & 19.87 & 19.29 & 19.30 & 19.01 \\
\hline $\begin{array}{l}\text { High-Tech } \\
\text { Products }\end{array}$ & 17.48 & 16.90 & 17.15 & 11.57 & 9.54 & 8.87 & 11.94 & 13.12 & 11.84 & 12.63 & 11.05 \\
\hline
\end{tabular}

Source: Ningbo Municipal Commission of Commerce.

Almost 50\% export products of Ningbo are labor intensive products, which can be divided into 3 kinds: the textile and apparel, electronic, lighting related products and machinery products (table 3 ). 
Table 3 Ningbo's major export commodity, 2004-2015[\%]

\begin{tabular}{|c|c|c|c|c|c|c|c|c|c|c|c|c|}
\hline & 2004 & 2005 & 2006 & 2007 & 2008 & 2009 & 2010 & 2011 & 2012 & 2013 & 2014 & 2015 \\
\hline $\begin{array}{l}\text { Clothing and } \\
\text { Clothing } \\
\text { Accessories }\end{array}$ & 16.03 & $\begin{array}{c}14.4 \\
1\end{array}$ & $\begin{array}{c}13.7 \\
7\end{array}$ & $\begin{array}{c}12.5 \\
5\end{array}$ & $\begin{array}{c}12.5 \\
1\end{array}$ & $\begin{array}{c}14.5 \\
4\end{array}$ & $\begin{array}{c}12.8 \\
5\end{array}$ & $\begin{array}{c}12.8 \\
6\end{array}$ & $\begin{array}{c}12.0 \\
5\end{array}$ & $\begin{array}{c}12.6 \\
2\end{array}$ & $\begin{array}{c}12.2 \\
3\end{array}$ & 11.90 \\
\hline $\begin{array}{l}\text { Textile yarn, } \\
\text { Fabrics and } \\
\text { Related Products }\end{array}$ & 8.62 & 7.90 & 8.21 & 7.35 & 7.44 & 7.56 & 6.78 & 6.88 & 6.92 & 6.94 & 6.91 & 6.72 \\
\hline Plastic Product & 3.60 & 3.41 & 3.18 & 2.20 & 1.92 & 2.61 & 2.77 & 2.88 & 3.20 & 3.40 & 3.61 & 3.66 \\
\hline Lcd Panel & & & & 4.04 & 5.35 & 3.94 & 3.43 & 2.77 & 3.04 & 2.11 & 1.51 & 1.36 \\
\hline Automobile Parts & 1.88 & 1.92 & 1.91 & 1.87 & 1.86 & 1.95 & 2.16 & 2.36 & 2.45 & 2.47 & 2.49 & 2.54 \\
\hline $\begin{array}{l}\text { Lamps and } \\
\text { Lighting Devices } \\
\text { and Similar } \\
\text { Products }\end{array}$ & 2.29 & 2.28 & 2.31 & 2.30 & 2.18 & 2.32 & 2.37 & 2.31 & 2.65 & 2.89 & 3.65 & 3.73 \\
\hline $\begin{array}{l}\text { Electrical Wires } \\
\text { and Cables }\end{array}$ & 1.81 & 1.95 & 2.20 & 2.25 & 2.17 & 1.85 & 1.85 & 1.82 & 1.85 & 1.77 & 1.68 & 1.55 \\
\hline $\begin{array}{l}\text { Steel or Copper } \\
\text { Standard Fasteners }\end{array}$ & 1.17 & 1.33 & 1.47 & 1.68 & 1.92 & 1.05 & 1.16 & 1.27 & 1.15 & 1.10 & 1.04 & 0.94 \\
\hline Container & 1.59 & 2.04 & 1.25 & 1.60 & 1.29 & NA & 1.01 & 1.22 & 0.92 & 0.76 & 0.97 & 0.00 \\
\hline $\begin{array}{l}\text { Furniture and its } \\
\text { Parts }\end{array}$ & 1.19 & 1.37 & 1.43 & 1.64 & 1.69 & 2.22 & 2.27 & 2.11 & 2.21 & 2.26 & 2.38 & 2.42 \\
\hline $\begin{array}{l}\text { Hige Protection } \\
\text { Circuit Device and } \\
\text { Parts }\end{array}$ & 1.04 & 1.01 & 1.03 & 0.97 & 0.86 & 0.98 & 1.15 & 1.11 & 1.15 & 1.23 & 1.32 & 1.47 \\
\hline Bearing & 1.57 & 1.41 & 1.22 & 1.10 & 1.11 & 1.01 & 1.16 & 1.31 & 1.16 & 1.11 & 1.14 & 1.11 \\
\hline Rolled Steel & & 0.87 & 1.68 & 1.97 & 2.04 & 0.95 & 1.35 & 1.44 & 1.18 & 1.26 & 1.54 & 1.39 \\
\hline Ship & NA & NA & NA & 1.15 & 2.47 & 3.94 & 3.17 & 2.40 & 1.66 & 1.78 & 1.37 & 1.46 \\
\hline $\begin{array}{l}\text { Bags and Similar } \\
\text { Container }\end{array}$ & 1.20 & NA & NA & NA & 0.98 & 0.94 & 0.96 & 0.95 & 0.87 & 0.91 & 1.03 & 0.99 \\
\hline $\begin{array}{l}\text { Diode and Similar } \\
\text { Semiconductor } \\
\text { Devices }\end{array}$ & NA & NA & NA & NA & 1.06 & 0.92 & 2.37 & 1.61 & 0.86 & 0.00 & 0.00 & 0.88 \\
\hline Shoes & NA & NA & NA & NA & 0.73 & 1.13 & 1.14 & 1.15 & 1.15 & 1.25 & 1.55 & 1.57 \\
\hline
\end{tabular}

Source: Original data collected from Ningbo Municipal Commission of Commerce, authors calculated.

Among exported products, more than $50 \%$ are mechanical and electrical products, high-tech products only $6.4 \%$ nearly years (table 4 ).

Table 4 The export share of mechanical and electrical, high-tech products, 2004-2015[\%]

\begin{tabular}{|c|c|c|c|c|c|c|c|c|c|c|c|c|}
\hline & 2004 & 2005 & 2006 & 2007 & 2008 & 2009 & 2010 & 2011 & 2012 & 2013 & 2014 & 2015 \\
\hline $\begin{array}{c}\text { Mechanical and } \\
\text { Electrical Products }\end{array}$ & 51.1 & 53.4 & 54.1 & 57.6 & 58.3 & 54.7 & 56.5 & 55.6 & 56.0 & 54.5 & 53.6 & 54.4 \\
\hline High Tech Products & 14.4 & 14.1 & 15.4 & 16.4 & 13.6 & 11.4 & 10.7 & 8.1 & 8.0 & 6.6 & 6.1 & 6.4 \\
\hline
\end{tabular}

Source: Original data collected from Ningbo Municipal Commission of Commerce, authors calculated.

Geographical Distribution. Ningbo has formed an all-round and diversified import and export market. Ningbo has been promoting foreign trade on all fronts, and established trade relations with 
the vast majority of the world's countries and regions. Over $82 \%$ Ningbo's products export to Asia, Europe and North America, its share in export total value is slightly decreasing, especially, the percentage in Asia falling from 35.52\% in 2004 to $30.87 \%$ in 2015, on the other hand its share in Sorth America and North America increase (table 5) .

Table 5 Geographical distribution of export products by region,2004-2015[\%]

\begin{tabular}{|r|r|r|r|r|r|r|r|r|r|r|r|r|}
\hline Region & 2004 & 2005 & 2006 & 2007 & 2008 & 2009 & 2010 & 2011 & 2012 & 2013 & 2014 & 2015 \\
\hline Asia & 35.52 & 32.31 & 31.51 & 32.19 & 31.37 & 32.75 & 30.05 & 30.58 & 30.75 & 30.95 & 30.76 & 30.87 \\
\hline Africa & 4.83 & 4.68 & 5.12 & 5.00 & 4.81 & 5.04 & 4.61 & 4.90 & 5.14 & 5.46 & 5.45 & 5.36 \\
\hline Europe & 31.67 & 33.47 & 33.35 & 34.07 & 35.06 & 32.68 & 33.79 & 33.04 & 30.13 & 30.27 & 30.56 & 29.25 \\
\hline $\begin{array}{r}\text { South } \\
\text { America }\end{array}$ & 5.39 & 5.39 & 6.27 & 6.44 & 7.21 & 6.86 & 8.07 & 8.78 & 9.21 & 8.71 & 8.08 & 7.92 \\
\hline $\begin{array}{r}\text { North } \\
\text { America }\end{array}$ & 19.12 & 21.00 & 20.55 & 19.39 & 18.45 & 19.31 & 19.90 & 19.60 & 21.49 & 21.41 & 22.11 & 23.33 \\
\hline Oceania & 3.48 & 3.14 & 3.21 & 2.92 & 3.10 & 3.36 & 3.58 & 3.09 & 3.27 & 3.21 & 3.05 & 3.28 \\
\hline
\end{tabular}

Source: Original data collected from Ningbo Municipal Commission of Commerce, authors calculated.

Ningbo import mainly products from regions of Asia, Europe and North America, its share in total import total value, about $62 \%, 13 \%$ and $11 \%$, respectively. Its share by regions is a little fluctuating, but stable (table 6).

Table 6 Geographical distribution of import product by region,2004-2015[\%]

\begin{tabular}{|l|l|l|l|l|l|l|l|l|l|l|l|}
\hline & & 2006 & 2007 & 2008 & 2009 & 2010 & 2011 & 2012 & 2013 & 2014 & 2015 \\
\hline Asia & 62.6 & 63.3 & 64.8 & 67.3 & 59.8 & 57.9 & 58.1 & 60.9 & 60.1 & 61.0 & 62.4 \\
\hline Europe & 16.4 & 13.5 & 12.7 & 11.6 & 15.0 & 14.7 & 13.7 & 12.6 & 12.0 & 11.5 & 11.2 \\
\hline $\begin{array}{l}\text { South } \\
\text { America }\end{array}$ & 4.1 & 4.7 & 5.7 & 7.1 & 8.7 & 9.6 & 9.2 & 8.5 & 6.2 & 6.3 & 5.4 \\
\hline $\begin{array}{l}\text { North } \\
\text { America }\end{array}$ & 11.1 & 11.2 & 12.4 & 9.5 & 10.1 & 10.6 & 11.5 & 10.3 & 10.8 & 9.4 & 10.0 \\
\hline Oceania & 2.0 & 2.6 & 3.2 & 3.4 & 4.7 & 5.3 & 5.2 & 5.8 & 8.5 & 9.7 & 9.0 \\
\hline
\end{tabular}

Ningbo international trade partners have increased from a small number of countries and regions in 1985 to over 220 countries and regions now. The United States, Germany, UK, Japan the other economies have become Ningbo's major export partners in 2015 (fig 2), and Taiwan of China, Japan, ROK, US and others are Ningbo major import partners (fig 3).

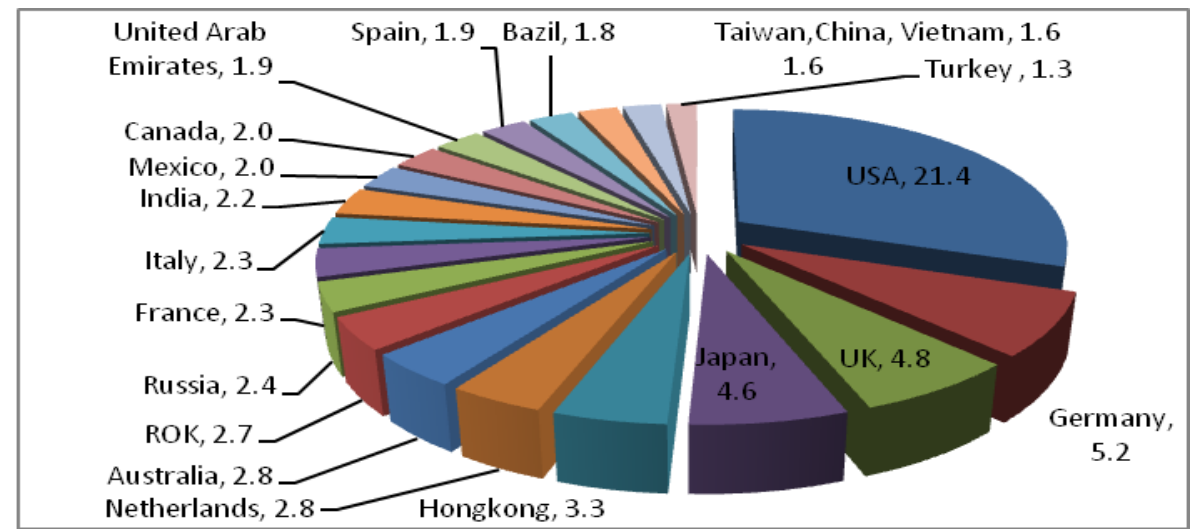

Figure 2. Ningbo's Top 20 Export Partners in 2015[\%] 
Source: Original data collected from Ningbo Municipal Commission of Commerce, authors calculated.

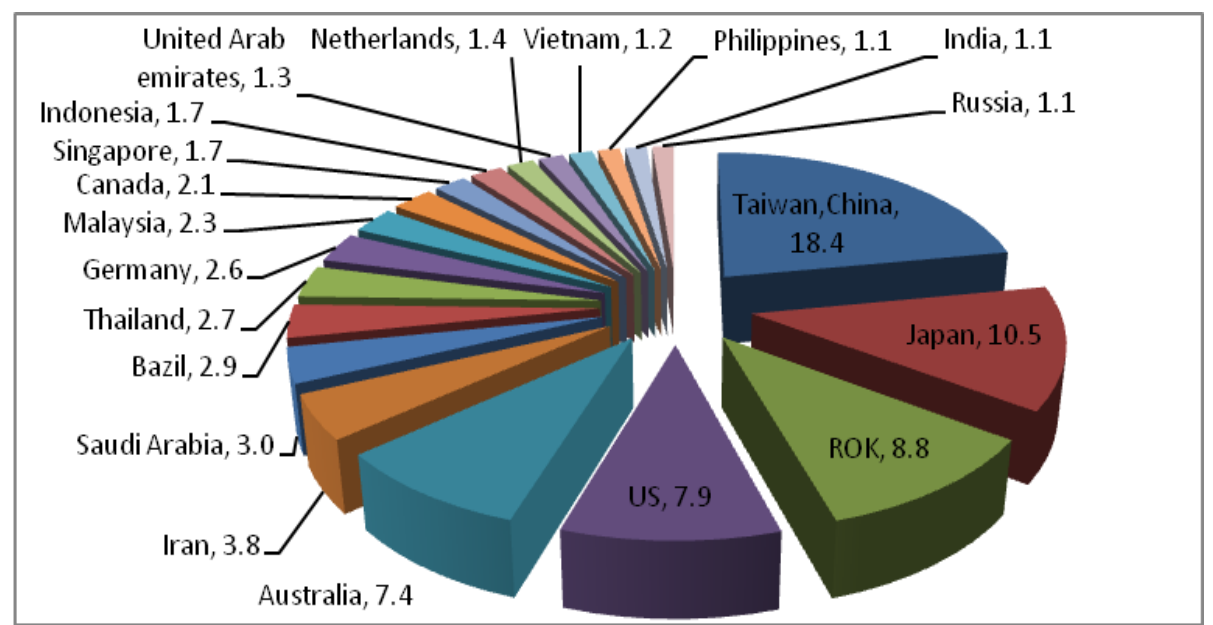

Figure 3. Ningbo' s Top 20 Import Partners in 2015[\%]

Source: Original data collected from Ningbo Municipal Commission of Commerce, authors calculated.

Grouped by Registered Type. Both foreign-invested enterprises and private enterprises have played very significant roles in Ningbo export and import goods. The export of private enterprises accounted for $46.2 \%$ in 2011 and reached to $62.1 \%$ in 2015, has played an important role, following with foreign-invested enterprises which took up 36\% in 2011 and rose to $27.9 \%$ in 2015.

In 2011, import of foreign funded enterprises accounted for nearly half of total imports, private enterprises and others took up $34 \%$, in 2015 the share of private enterprises and others rose to $46.5 \%$, and foreign funded enterprises decreased to $42.1 \%$.

Competitiveness of Electromechanical and High-Tech Products. Trade Competitiveness Index (TCI) can be formulated as ratio of the balance of import \& export to the total import and export in that region. TCI varies between -1 to 1 , higher ratio being indicative of higher international trade competitiveness. When the index is less than zero, it shows) that the competitiveness of the region is weak.

Calculating TCI of Ningbo Electromechanical and High-Tech Products by the formula mentioned above, TCI of Electromechanical products increased from 0.59 in 2005 to 0.75 in 2015 table 7) , proving that this sort of goods enjoy stronger international trade competitiveness.

During the period of 2005 to 2010, TCI of new high-tech products almost rose from 0.23 in 2005 to 0.43 in 2008, dropped in 2009, this indicated that new high-tech products have higher competitiveness in the international market before 2009. Owing to the adjustment of China's high-tech products export directory, some exporting high-tech products in the old version were not be listed on the new edition, the TCI decreased radically in 2011 (table 7), the competitiveness of high-tech product became weakness.

Table 7 Trade competitiveness index of electromechanical and high-tech products, 2005-2015

\begin{tabular}{|l|c|c|c|c|c|c|c|c|c|c|c|}
\hline & 2005 & 2006 & 2007 & 2008 & 2009 & 2010 & 2011 & 2012 & 2013 & 2014 & 2015 \\
\hline $\begin{array}{c}\text { High-Tech } \\
\text { Products }\end{array}$ & 0.23 & 0.32 & 0.34 & 0.43 & 0.35 & 0.34 & 0.05 & 0.03 & 0.03 & 0.05 & 0.18 \\
\hline $\begin{array}{l}\text { Electromec } \\
\text { hanical } \\
\text { Products }\end{array}$ & 0.59 & 0.65 & 0.64 & 0.63 & 0.62 & 0.64 & 0.67 & 0.66 & 0.69 & 0.73 & 0.75 \\
\hline
\end{tabular}




\section{Influence on Economic Growth: Empirical Test}

Literature Review. International trade, being known as an important factor in the economic growth process, is believed to be one of engine of economic growth[5]. The relationship between trade openness and economic growth received a growing interest in the abundant literature the last decades[7]. However, both the theoretical and empirical results are mixed. Most of empirical studies overwhelmingly prove a positive and statistically significant relationship between trade openness and growth [1,2,6]; Others find negative effect of trade openness on economic growth[3]. There is little empirical work on this subject in Ningbo[8].

This paper employs the empirical model used by Were(2015)[4], the model list as below:

$$
\operatorname{Rgdpp}_{i t}=\alpha+\beta_{1} \text { Trade }_{i t}+\beta_{2} \text { Rsss }_{i t}+\beta_{3} \text { Rpopulation }_{i t}+\beta_{4} \text { Lgdpp }_{i t}+\varepsilon_{i t}
$$

i- county-level city i of Ningbo, Yinzhou, Yuyao, Cixi, Fenghua, Xiangshan,Ninghai

$\mathrm{t}-2005,2006,2007 \ldots 2014$

Where RGDPP is rate of growth of real GDP per capita for region $i$ in the period of $t$, trade is the trade openness measure for region $i$, measured by the sum of trade(exports plus imports), export and import as a share of GDP respectively. Lgdpp, Rsss, Rpopulation are control variables which is normally included to control for convergence [4] and cis the error term. The control variable Lgdpp is calculated by real GDP per capita of region i, , it can also be interpreted as a proxy for stock of capital for a country[9]. RSSS is rate of growth of human capital approximated by the growth rate of senior secondary school enrolment. In addition, Rpopulation means population growth.

This empirical research of the relationship between trade openness and economic growth uses county-level city panel data annual covering the period 2005-2014. All data needed, source from both Ningbo Statistical Yearbook 2004-2015 and Ningbo Municipal Commission of Commerce.

Estimated Results. Our sample in provincal panel data test are composed of 6 county-level cities for the period 2005 to 2014, whose statistics are shown in Table7 below. As can be seen, there are 60 dependent variable and independent variable in the regression, respectively.

Table 8 Panel data summary statistics

\begin{tabular}{|c|c|c|c|c|c|c|}
\hline Variable & & Mean & Std. Dev. & Min & Max & Observations \\
\hline \multirow[t]{3}{*}{ Rgdpp } & overall & \multirow[t]{3}{*}{.1289595} & .0604665 & .0072764 & .2644992 & $\mathrm{~N}=60$ \\
\hline & between & & .0168634 & .108134 & .1560491 & $\mathrm{n}=6$ \\
\hline & within & & .0584397 & .0132374 & .2540602 & $\mathrm{~T}=10$ \\
\hline \multirow[t]{3}{*}{ Lgdpp } & overall & \multirow[t]{3}{*}{10.94248} & .4398225 & 10.00906 & 11.93985 & $\mathrm{~N}=60$ \\
\hline & between & & .3066778 & 10.64038 & 11.42026 & $\mathrm{n}=6$ \\
\hline & within & & .3372527 & 10.22589 & 11.46207 & $\mathrm{~T}=10$ \\
\hline \multirow[t]{3}{*}{ etrade } & overall & \multirow[t]{3}{*}{.0768829} & .0159811 & .0477408 & .1053041 & $\mathrm{~N}=60$ \\
\hline & between & & .0162323 & .0576677 & .0966949 & $\mathrm{n}=6$ \\
\hline & within & & .0056659 & .0610521 & .0876288 & $\mathrm{~T}=10$ \\
\hline \multirow[t]{3}{*}{ itrade } & overall & \multirow[t]{3}{*}{.016993} & .0100565 & .0032802 & .0518448 & $\mathrm{~N}=60$ \\
\hline & between & & .0092351 & .0052323 & .0251035 & $\mathrm{n}=6$ \\
\hline & within & & .0053717 & .0066284 & .0449763 & $\mathrm{~T}=10$ \\
\hline \multirow[t]{3}{*}{ ietrade } & overall & \multirow[t]{3}{*}{.0938759} & .0237899 & .0534203 & .1347444 & $\mathrm{~N}=60$ \\
\hline & between & & .0244656 & .0635556 & .1211033 & $\mathrm{n}=6$ \\
\hline & within & & .0076615 & .0789382 & .1217322 & $\mathrm{~T}=10$ \\
\hline \multirow[t]{3}{*}{ Rsss } & overall & \multirow[t]{3}{*}{-.0916667} & .269778 & -.71 & .7 & $\mathrm{~N}=54$ \\
\hline & between & & .0125659 & -.1077778 & -.0744444 & $\mathrm{n}=6$ \\
\hline & within & & .2695294 & -.7172222 & .6827778 & $\mathrm{~T}=9$ \\
\hline \multirow{3}{*}{$\begin{array}{l}\text { Rpopulatio } \\
\text { n }\end{array}$} & overall & \multirow[t]{3}{*}{.4666667} & .3968719 & -.25 & 1.42 & $\mathrm{~N}=60$ \\
\hline & between & & .3657877 & .091 & 1.048 & $\mathrm{~N}=6$ \\
\hline & within & & .2100403 & -.2473333 & .8986666 & $\mathrm{~T}=10$ \\
\hline
\end{tabular}


Firstly, to judge which one is appropriate for our model by Hausman's (1978) specification test using STATA 10.0, random-effects specification or fixed-effects. The results confirm random-effects specification is apply to model 1 , model 2 and model 3 under $1 \%$ level. Secondly, we estimate model 1, model 2 and model 3 according to the specification (1) using an ordinary least square estimation. The regression results are presented in Table 9.

Table 9 Regression results for trade share and economic growth

\begin{tabular}{|c|c|c|c|}
\hline \multirow[t]{2}{*}{ COEFFICIENT } & model 1 & model 2 & model 3 \\
\hline & Rgdpp & Rgdpp & Rgdpp \\
\hline Lgdpp & $\begin{array}{c}-0.0991^{* * * 3} \\
(0.016)\end{array}$ & $\begin{array}{c}-0.0782^{* * * *} \\
(0.017)\end{array}$ & $\begin{array}{c}-0.0973^{* * x^{2}}(0.017)\end{array}$ \\
\hline Rsss & $\begin{array}{c}c_{0.0954^{\text {**** }}}(0.020)\end{array}$ & $\begin{array}{c}0.110^{* * *} \\
(0.022)\end{array}$ & $\begin{array}{c}0.100^{* * * *} \\
(0.020)\end{array}$ \\
\hline Rpopulation & $\begin{array}{c}0.0463^{\text {**** }} \\
(0.014)\end{array}$ & $\begin{array}{c}0.0545^{* * *} \\
(0.016)\end{array}$ & $\begin{array}{c}0.0520^{* * * *} \\
(0.014)\end{array}$ \\
\hline Etrade & $\begin{array}{c}1.919^{* * * *} \\
(0.42)\end{array}$ & & \\
\hline Itrade & & $\begin{array}{l}1.921^{* *} \\
(0.75)\end{array}$ & \\
\hline Trade & & & $\begin{array}{c}1.211^{* * *} \\
(0.29)\end{array}$ \\
\hline Constant & $\begin{array}{c}1.054^{* * *} \\
(0.16)\end{array}$ & $\begin{array}{c}0.938^{* * *} \\
(0.18)\end{array}$ & $\begin{array}{c}1.066^{* * * *} \\
(0.17)\end{array}$ \\
\hline Observations & 54 & 54 & 54 \\
\hline Number of id & 6 & 6 & 6 \\
\hline R-squared & . & . & . \\
\hline Hausman & $\mathrm{Re}$ & $\mathrm{Re}$ & $\mathrm{Re}$ \\
\hline
\end{tabular}

Standard errors in parentheses

$* * * \mathrm{p}<0.01, * * \mathrm{p}<0.05, * \mathrm{p}<0.1$

\section{Conclusion}

Ningbo international trade has increased at an average annual growth rate of $35.8 \%$ since 1985 . Analyzing its international trade, we can deduce some finding: firstly, the export or import market is characterized by developed regions or close to Ningbo city. Asia, Europe and North America are three biggest export and import markets in the world, USA, Germany, UK, Japan and Hongkong of China are important export partners, while Taiwan of China, Japan, ROK and US are Ningbo major import partners of Ningbo. Secondly, Ningbo exports labor intensive products and imports technology intensive goods. Thirdly, Ningbo Electromechanical products show a stronger competitiveness from 2005 to 2015, because of its TCI of more than 0.59 .

The empirical results show a positive and significant impact of trade on economic growth in the period 2005 to 2014 . The empirical analysis also supports the increasing role of trade in economic development. Due to not capturing suitable independent variable now, we also consider that there exists some omitted variables in econometric model. In the future, we will deepen the empirical research.

\section{Acknowledgement}

Ningbo Philosophy and Social Sciences Planning Project of 2016, No: G16-ZX33

Ningbo Soft Science Project of 2016, No: 2016A10017

\section{References}

[1] Barro, R. Economic growth in a cross section of countries. Quarterly Journal of Economics, 106, (1991)407-443.

[2] Frankel, J.N., Romer, D., Does trade cause growth? Am. Econ. Rev. 89, (1999)379-399. 
[3] Jacob W. Musila, Zelealem Yiheyis, The impact of trade openness on growth: The case of KenyaJournal of Policy Modeling 37 (2015) 342-354.

[4] Maureen Were. Differential effects of trade on economic growth and investment: A cross-country empirical investigation, Journal of African Trade 2 (2015) 71-85.

[5] Mounir Belloumi, The relationship between trade, FDI and economic growth in Tunisia: An application of the autoregressive distributed lag model Economic Systems 38 (2014) 269-287.

[6] Onafowora, O.A., Owoye, O., Can trade liberalization stimulate economic growth in Africa? World Dev. 26 (3), (1998)497-506.

[7] Rajagopal, Trade openness and inflation in latin american countries, Economic Studies of International Development Vol.7-1(2007)77-98.

[8] Wang haohan, Ding yuanyao, Wun wenbo. Analysis of contribution rate on effect factors of regional economic growth-for Ningbo city. Economy geography, vol.23, no.5 (2003) 593-664 (in Chinese).

[9] Yanikkaya, H., Trade openness and economic growth: a cross-country empirical investigation, Journal of Development Economics, Volume 72, (2003)57- 89.

\section{Author in Brief}

GAO Zhixiong, Ph.D., associate professor, mainly engaged in international trade, Multinational companies and foreign direct investment. E-mail: gzxuibe@126.com. 